\title{
Synthesis and Characterization of Thymidine Adducts of Arylamines
}

\section{N. V. Anil Kumar \& K. S. Rangappa}

To cite this article: N. V. Anil Kumar \& K. S. Rangappa (2003) Synthesis and Characterization of Thymidine Adducts of Arylamines, Synthetic Communications, 33:2, 259-264, DOI: 10.1081/ SCC-120015711

To link to this article: https://doi.org/10.1081/SCC-120015711

曲 Published online: 21 Aug 2006.

Submit your article to this journal $\pi$

Џlll Article views: 190

Q View related articles $₫$

4 Citing articles: 1 View citing articles 
○2003 Marcel Dekker, Inc. All rights reserved. This material may not be used or reproduced in any form without the express written permission of Marcel Dekker, Inc.

SYNTHETIC COMMUNICATIONS ${ }^{\circledR}$

Vol. 33, No. 2, pp. 259-264, 2003

\title{
Synthesis and Characterization of Thymidine Adducts of Arylamines
}

\author{
N. V. Anil Kumar and K. S. Rangappa* \\ Department of Studies in Chemistry, Manasa Gangotri, \\ University of Mysore, Mysore, India
}

\begin{abstract}
The synthesis of adducts of arylamines with thymidine are reported.

Key Words: Thymidine adducts; Synthesis; Characterization.
\end{abstract}

Aromatic amines and nitroarenes are very important industrial intermediates. Several scientists ${ }^{[1,2]}$ have extensively studied the covalent binding of a number of aromatic amines to DNA and identified various products by studying the in vivo and in vitro reactions of esters of aryl hydroxylamine. ${ }^{[3]} \mathrm{N}$-Oxidation is

*Correspondence: K. S. Rangappa, Department of Studies in Chemistry, Manasa Gangotri, University of Mysore, Mysore 570 006, India. Fax: +91-821-518835 or 421263; E-mail: rangappaks@yahoo.com.

259

DOI: $10.1081 /$ SCC-120015711

Copyright @ 2003 by Marcel Dekker, Inc.
0039-7911 (Print); 1532-2432 (Online) www.dekker.com 
a key step in the metabolism of aromatic amines and amides to toxic products. Aromatic amines can be metabolized to highly reactive $N$-hydroxy aromatic amines. These are highly reactive intermediates, which are responsible for the genotoxic effects of this class of compounds. DNA adducts of arylamines have been found in several organs of exposed experimental animals. With the advancement in analytical technique, scientists have quantified the DNA adducts of arylamines in human tissue. Therefore, the reference standards of DNA adducts have been synthesized. The deoxyguanosine adducts or arylamines from various animal sources by synthesis are known ${ }^{[4-6]}$ but not the thymidine adducts and therefore, this study of the reaction of arylamines with thymidine is undertaken.

In the present study, the thymidine adducts of the monocyclic arylamines are synthesized, which can be used to develop ${ }^{32} \mathrm{P}$-postlabeling and mass spectrometric methods for low-level detection in biological material.

This synthetic route was based on observations by Lobo et al. ${ }^{[7,8]}$ on the reaction of $N$-benzoyloxy- $N$-arylamines with nucleophiles under basic conditions. The DNA adducts of arylamines are synthesized from the corresponding $\mathrm{N}$-benzoyloxy arylamines and nucleoside. These $\mathrm{N}$ benzoyloxy compounds are obtained after the reaction of the corresponding $N$-hydroxy arylamines treated with benzoyl chloride at below $0^{\circ} \mathrm{C}$. The freshly prepared solution of the $N$-benzoyloxy- $N$-arylamine was added to the aqueous solution of thymidine. The resulting mixture was purified by solvent extraction (Sch. 1). N-Benzoyloxy compounds have also been isolated and characterized by NMR and IR spectroscopy.

All NMR experiments were performed with $d_{6}$-DMSO as solvent. The peaks were assigned according to the spectra of thymidine. In the ${ }^{1} \mathrm{H}$ NMR spectra of the thymidine adducts, the peak of $6 \mathrm{H}$ disappears and the NH proton of the arylamine shifted downfield by $3 \mathrm{ppm}$. The C-6 peak for unmodified thymidine is $124 \mathrm{ppm}$ where as the C-6 peak shifted to $137-140 \mathrm{ppm}$ for the adducts. In the ${ }^{13} \mathrm{C}$ NMR spectra, the C-2' peak of the sugar in the adducts is shifted slightly upfield by $1 \mathrm{ppm}$ and the resonance of C-5 is shifted by $3 \mathrm{ppm}$. It is important to note that $\mathrm{C}-1$ peak of arylamine is shifted upfield by about 8 ppm.

The UV spectra (methanol/water) of thymidine adducts were shifted to longer wavelengths by $10-45 \mathrm{~nm}$ compared to thymidine alone, depending on the adduct. 
(C)2003 Marcel Dekker, Inc. All rights reserved. This material may not be used or reproduced in any form without the express written permission of Marcel Dekker, Inc.

Thymidine Adducts of Arylamines

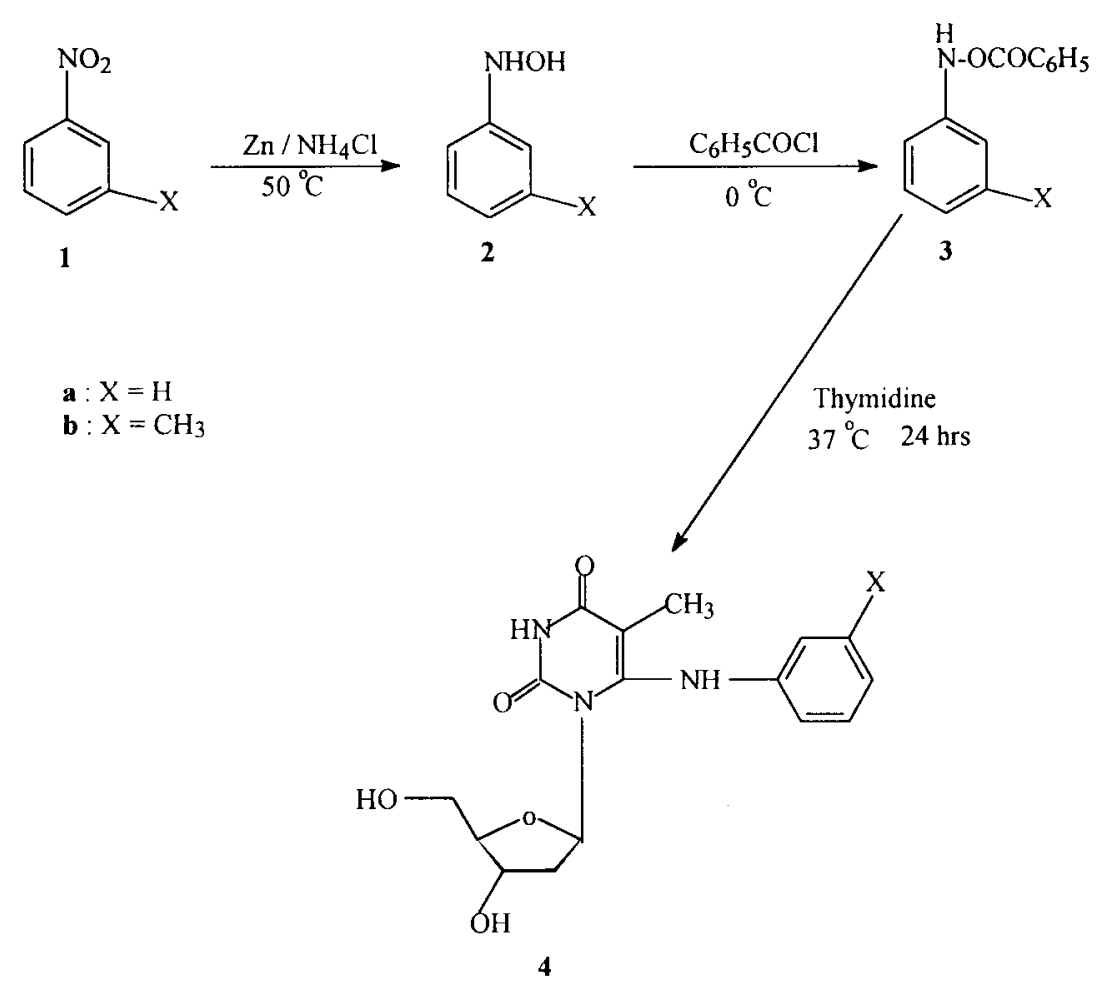

Scheme 1.

\section{EXPERIMENTAL}

\section{Synthesis and Characterization of $N$-(thymidin-6-yl)-aniline (4a)}

To a stirred solution of nitro benzene (1a, $8 \mathrm{mmol}, 0.985 \mathrm{~g})$, ammonium chloride $(0.5 \mathrm{~g})$ and ammonium hydroxide $(2 \mathrm{~mL})$ were added in water $(40 \mathrm{~mL})$. The solution was heated to $50^{\circ} \mathrm{C}$. Zinc $(17.6 \mathrm{mmol}$, $1.1509 \mathrm{~g}$ ) was added in such a way that the temperature does not rise above $60^{\circ} \mathrm{C}$. Reaction was monitored by thin layer chromatography (TLC). After the reduction of nitro benzene, reaction mixture was cooled to room temperature, and filtered. The filtrate was saturated with sodium chloride and cooled in ice bath. This was extracted with ether:benzene $(1: 1 \mathrm{v} / \mathrm{v}, 4 \times 35 \mathrm{~mL})$. The 
organic layer was dried over anhydrous magnesium sulphate and the solvent was evaporated. The product, $N$-phenyl hydroxylamine (2a), so obtained was further purified by washing with $n$-hexane followed by cyclohexane. The pure hydroxylamine (2a) was, characterized by m.p., NMR, and IR, which is in confirmation with the reported data. ${ }^{[9]}$

To a solution of aryl hydroxylamine (2a, $2 \mathrm{mmol}, 0.2183 \mathrm{~g}$ ) in dry ether (cooled in the ice bath), ice-cold benzoylchloride $(2.4 \mathrm{mmol}$, $0.3374 \mathrm{~g}$ ) in dry ether was added. The rate of addition of benzoylchloride was such that the temperature does not rise above $0^{\circ} \mathrm{C}$. The solution was stirred vigorously for $3 \mathrm{~h}$, and the reaction mixture was stirred for another $30 \mathrm{~min}$ so that it attains room temperature. Finally, this was neutralized with saturated solution of sodium bicarbonate. The organic layer was dried over anhydrous sodium acetate and the solvent was evaporated. The product was purified by recrystallization with water. Pure $N$-benzoyloxy- $N$-phenyl hydroxylamine (3a) was characterized by m.p., NMR, and IR. Data obtained were in good agreement with the reported data. ${ }^{[9]}$

To the ester (3a, $0.206 \mathrm{mmol}, 43.98 \mathrm{mg}$ ) in chloroform:alcohol: water $(7: 3: 4 \mathrm{v} / \mathrm{v}, 35 \mathrm{~mL})$, was added triethylamine $(0.2 \mathrm{~mL})$. The temperature was maintained at $37^{\circ} \mathrm{C}$. Thymidine $(0.206 \mathrm{mmol}, 50.00 \mathrm{mg})$ was added to a stirred reaction mixture and the reaction was monitored by TLC. After $24 \mathrm{~h}$, the reaction mixture was evaporated to dryness and redissolved in water. This was extracted with diethyl ether $(4 \times 50 \mathrm{~mL})$ and $n$-butanol $(3 \times 25 \mathrm{~mL})$. The $n$-butanol extract was concentrated in vacuo. Yield $=3.2 \mathrm{mg}(4.7 \%)$. Analysis of the product $(\mathbf{4 a})$ by HPLC [chloroform:methanol $(50: 50 \mathrm{v} / \mathrm{v}), \lambda=264 \mathrm{~nm}$ ] showed $98.9 \%$ purity. This was characterized by ${ }^{1} \mathrm{H}$ and ${ }^{13} \mathrm{C} \mathrm{NMR}$.

Elemental analysis of 4a: (Calcd.) C 57.65\%, H 5.74\%, N 12.61\%; (found) C $57.68 \%, \mathrm{H} 5.71 \%, \mathrm{~N} 12.64 \%$.

1H NMR of 4a: (400 MHz, $d_{6}$-DMSO): $\delta(\mathrm{ppm}): 1.84\left(\mathrm{~m}, 1 \mathrm{H}, 2^{\prime} \mathrm{H}\right)$; $2.51\left(\mathrm{~m}, 1 \mathrm{H}, 2^{\prime} \mathrm{H}\right) ; 2.12\left(\mathrm{~s}, 3 \mathrm{H}, \mathrm{CH}_{3}\right) ; 3.66\left(\mathrm{~m}, 2 \mathrm{H}, 5^{\prime} \mathrm{H}\right) ; 3.83(\mathrm{~m}$, $\left.1 \mathrm{H}, 4^{\prime} \mathrm{H}\right) ; 4.24\left(\mathrm{~m}, 1 \mathrm{H}, 3^{\prime} \mathrm{H}\right) ; 4.84(\mathrm{~s}, 1 \mathrm{H}, \operatorname{Ar}-\mathrm{NH}) ; 5.02(\mathrm{~s}, 1 \mathrm{H}$, $\left.3^{\prime} \mathrm{OH}\right) ; 5.20\left(\mathrm{~s}, 1 \mathrm{H}, 5^{\prime} \mathrm{OH}\right) ; 6.24\left(\mathrm{q}, 1 \mathrm{H}, 1^{\prime} \mathrm{H}\right) ; 6.42(\mathrm{q}, 2 \mathrm{H}, \operatorname{Ar}-2 \mathrm{H}$, Ar-6H); 6.61 (d, 1H, Ar-4H); 6.94 (q, 2H, Ar-3H, Ar-5H); 7.76 (s, 1H, NH).

${ }^{13} \mathrm{CNMR}$ of 4a: $\left(400 \mathrm{MHz}, d_{6}\right.$-DMSO): $\delta$ (ppm): $12.26\left(\mathrm{CH}_{3}\right)$; 39.39 (2'C); $61.36\left(5^{\prime} \mathrm{C}\right) ; 70.49\left(3^{\prime} \mathrm{C}\right) ; 83.72\left(1^{\prime} \mathrm{C}\right) ; 87.27\left(4^{\prime} \mathrm{C}\right) ; 110.08$ (5C); $116.34 \quad$ (Ar-2C); $116.42 \quad$ (Ar-6C); $120.14 \quad$ (Ar-4C); 127.5 (Ar-5C); 128.14 (Ar-3C); 136.73 (6C); 139.41 (Ar-1C); 150.42 (2C); 153.69 (4C). 


\section{Synthesis and Characterization of $N$-(Thymidin-6-yl)-3-methylaniline (4b)}

The procedure for the synthesis of $\mathbf{4 b}$ is similar to that of $\mathbf{4 a}$. In this case, $8 \mathrm{mmol}$ of $\mathbf{1 b}, 2 \mathrm{mmol}$ of $\mathbf{2 b}$, and $0.206 \mathrm{mmol}$ of $\mathbf{3 b}$ were used to get $4.9 \mathrm{mg}(6.9 \%)$ of the product $\mathbf{4 b}$. Analysis of the product (4b) by HPLC [chloroform:methanol $(50: 50 \mathrm{v} / \mathrm{v}), \lambda=264 \mathrm{~nm}$ ] showed $99.2 \%$ purity. This was characterized by ${ }^{1} \mathrm{H}$ and ${ }^{13} \mathrm{C}$ NMR.

Elemental analysis of $\mathbf{4 b}$ : (Calcd.) C $58.78 \%, \mathrm{H} 6.09 \%, \mathrm{~N}$ $12.10 \%$; (found) $\mathrm{C} 58.80 \%, \mathrm{H} 6.07 \%, \mathrm{~N} 12.11 \%$.

${ }^{1} \mathrm{H}$ NMR of $\mathbf{4 b}:\left(400 \mathrm{MHz}, d_{6}\right.$-DMSO): $\delta(\mathrm{ppm}): 1.82\left(\mathrm{~m}, 1 \mathrm{H}, 2^{\prime} \mathrm{H}\right)$; $2.51\left(\mathrm{~m}, 1 \mathrm{H}, 2^{\prime} \mathrm{H}\right) ; 2.13\left(\mathrm{~s}, 3 \mathrm{H}, \mathrm{CH}_{3}\right) ; 2.56\left(\mathrm{~s}, 3 \mathrm{H}, \mathrm{Ar}-\mathrm{CH}_{3}\right) ; 3.68(\mathrm{~m}, 2 \mathrm{H}$, $\left.5^{\prime} \mathrm{H}\right) ; 3.79\left(\mathrm{~m}, 1 \mathrm{H}, 4^{\prime} \mathrm{H}\right) ; 4.23\left(\mathrm{~m}, 1 \mathrm{H}, 3^{\prime} \mathrm{H}\right) ; 4.92(\mathrm{~s}, 1 \mathrm{H}, \mathrm{Ar}-\mathrm{NH}) ; 4.99(\mathrm{~s}$, $\left.1 \mathrm{H}, 3^{\prime} \mathrm{OH}\right) ; 5.22\left(\mathrm{~s}, 1 \mathrm{H}, 5^{\prime} \mathrm{OH}\right) ; 6.21\left(\mathrm{q}, 1 \mathrm{H}, 1^{\prime} \mathrm{H}\right) ; 6.47(\mathrm{q}, 1 \mathrm{H}, \mathrm{Ar}-4 \mathrm{H})$; $6.59(\mathrm{q}, 1 \mathrm{H}, \operatorname{Ar}-6 \mathrm{H}) ; 6.89(\mathrm{~m}, 1 \mathrm{H}, \operatorname{Ar}-5 \mathrm{H}) ; 7.02(\mathrm{q}, 1 \mathrm{H}, \operatorname{Ar}-2 \mathrm{H}) ; 7.69$ (s, $1 \mathrm{H}, \mathrm{NH})$.

${ }^{13} \mathrm{C}$ NMR of $4 \mathbf{b}:\left(400 \mathrm{MHz}, d_{6}\right.$-DMSO): $\delta(\mathrm{ppm}): 12.21\left(\mathrm{CH}_{3}\right) ; 17.92$ $\left(\mathrm{Ar}-\mathrm{CH}_{3}\right) ; 39.35\left(2^{\prime} \mathrm{C}\right) ; 61.26\left(5^{\prime} \mathrm{C}\right) ; 70.29\left(3^{\prime} \mathrm{C}\right) ; 83.62\left(1^{\prime} \mathrm{C}\right) ; 87.15\left(4^{\prime} \mathrm{C}\right)$; 109.49 (5C); 118.92 (Ar-6C); 120.72 (Ar-4C); 122.47 (Ar-3C); 125.93 (Ar-2C); 128.42 (Ar-5C); 138.27 (Ar-1C); 139.84 (6C); 150.32 (2C); $153.58(4 \mathrm{C})$.

\section{ACKNOWLEDGMENT}

The authors would like to thank the Council of Scientific and Industrial Research (CSIR), New Delhi for the financial support (No. 01/1458/97-EMR II).

\section{REFERENCES}

1. Berenblum, I. Prog. Exp. Tumor Res. 1969, 11, 21.

2. Foulds, L. Neoplastic Development; Academic Press: New York, 1969; Vol. 1.

3. Kriek, E.; Westra, J.G. Chemical Carcinogenesis and DNA; CRC Press: Boca Raton, 1979; Vol. 2, p. 1.

4. Bosold, F.; Boche, G. Angew. Chem. Int. Ed. Eng. 1990, 29, 63.

5. Mallesha, H.; Ravi Kumar, K.R.; Mantelingu, K.; Rangappa, K.S. Synthesis 2001, 10, 1459.

6. Mallesha, H.; Ravi Kumar, K.R.; Rangappa, K.S. Synthesis 2001, MS No. Z-087/07/01. in press. 
C일 2003 Marcel Dekker, Inc. All rights reserved. This material may not be used or reproduced in any form without the express written permission of Marcel Dekker, Inc.

7. Prabhakar, S.; Lobo, A.M.; Marques, M.M. Tetrahedron Lett. 1982, 23, 1391.

8. Lobo, A.M.; Marques, M.M.; Prabhakar, S.; Rzepa, H.S. J. Chem. Soc. Chem. Commn. 1985, 1113.

9. Tomas Bube. Ph.D. Thesis, The Philipps Universitat: Marburg, 1994.

Received in the Netherlands December 10, 2001 